\title{
On (De) Personification in Prophet Muhammad's Tradition
}

\author{
Ahmad El-Sharif \\ Department of English Language and Literatur, Al-alBayt University, Jordan \\ E-mail: a.el-sharif@aabu.edu.jo
}

Doi:10.7575/aiac.alls.v.6n.6p.153

Received: 15/07/2015

URL: http://dx.doi.org/10.7575/aiac.alls.v.6n.6p.153

Accepted: 21/09/2015

\begin{abstract}
In this paper, I discuss the themes of personification and de-personification in the Prophet Muhammad's Tradition from a cognitive linguistic viewpoint. Instances of personification and de- personification in Prophet Muhammad's Tradition are analysed following approaches of conceptual metaphor theory and critical metaphor analysis. The analysis reveals that the two linguistic phenomena are eminent in the language of the Prophet Muhammad. Personification, for instance, is frequently used for ontological purposes to portray and conceptualise non-human entities such as abstract concepts, body parts, and human deeds. De-personification, on the other hand, is used to evoke more prevalent ideological implication whereby people are classified into a hierarchical scale according to the degree of their faith and the nature of their deeds and behaviours.
\end{abstract}

Keywords: Personification, Islam, Prophet Muhammad's Tradition, Conceptual Metaphor Theory

\section{Introduction}

Personification is a common linguistic phenomenon that can be found in almost in all types of discourse. This linguistic phenomenon is broadly recognised as a discursive device by which some human qualities, traits, and dispositions are bestowed upon inhuman creatures, inanimate objects, ideas and abstract notions. The term 'personification' (or anthropomorphism from the Greek (anthrōpos) "human" and (morphē) "form") was coined in the mid of the seventeenth century (Peter, 2004). In rhetoric, 'personification' typically refers to the instance in language where the speaker or the writer refers to an inanimate 'character' using the actions and personalities typically attributed to humans. The Penguin Dictionary of Literary Terms and Literary Theories defines personification as a figure of speech used to give a human form, to humanize inanimate objects, abstract entities, phenomena, and ideas (Cuddon, 1998).

In folk literature, for instance, personification is traditionally used to represent abstract and immaterial ideas and perpetual natural phenomena. The function of personification here is likened to that of metaphor where we describe something by comparing it to something more recognizable. For instance, abstract concepts, emotional states, and natural forces are bestowed human characteristics in myth and literature (See Paul De Man, 1988 (cited in Paxson, 1994)). Many cultures conventionally understand death in terms of human qualities. Thus, death is perceived as a gluttonous devourer, a destroyer, or a separator supernatural force that reflects the same intrinsic human qualities and portrayed using the folk image of the 'Grim Reaper' (See Bender, 1894; Hamilton, 2002). In addition, fiction across cultures attributes human qualities to animals, plants, and inanimate objects. Thus, we have animals and plants which can talk, think, love, and even invent tools. The moral messages of such fiction, such as Aesop's fables and the Grimms' fairy tales, exhibit some human traits by personifying animals and plants and making them behave like humans. Besides, personification is constantly employed in fiction to commercialise ideological messages. For example, George Orwell's Animal Farm and its criticism to communism and totalitarianism through the language and actions of 'empowered' farm animals.

Modern conceptual theories of metaphor regard personification as a key component and product of the metaphorical apparatus used in language, discourse, and thought. Craig Hamilton proposes "a metaphor in language normally reveals a related conceptual metaphor in thought" (Gibbs, 1996: 311); thus, the reason people resort to personification is that because they first think in personification (Hamilton, 2002). Where a conceptual metaphor is represented in terms of an abstract Target domain and a concrete Source one, personification, as a conceptual representation, involves a prevalent overlap with other metaphorical domains on the other. Back to earliest definitions of personification, it is perceived as the attribution of human features to inanimate objects (Leech, 1969). Herein, personification in contemporary theories of metaphor is recognised as a tool which the one is essentially use as ornamentation trope and for the goal of persuasion (Lakoff and Turner, 1989). Personification was then described in relation to the EVENTS ARE ACTIONS metaphor, which allows us to "conceive of agentless events as if they were caused by agents" (Lakoff and Turner, 1989: 36). What is most remarkable is how several metaphorical domains can be also understood in terms of their common characteristics with personification (See Eubanks, 2000; Gibbs, 1994; Grady, 1997; Kovecses, 1995). George Lakoff (1987) points to several conceptual metaphors of 'life' and 'death' using 'time' as a depiction of human experiences reflected through the conceptual metaphor TIME IS A THIEF. In other instances, personification extends its scope to overlap with other generic metaphorical domains such as JOURNEY, CONFLICT, NATURAL DISASTERS, or ANIMAL conceptual domains. Metaphors from such domains of experience involve some basic reflections and 
generalisations of personification once we regard the actions, or the processes, which the Target domains are engaged in. In this regard, personification can be identified with a more basic units of meaning associated an animate or human agency as in nouns, adverbs, and mostly adjective and verbs (Dorst, 2011: 120). These generalizations can be understood on the basis of the Halliday's transitivity perspective which looks into the ideational function of the text and the manner by which ideas are transmitted through language. Transitivity then is used to represent ' 'processes' or 'experiences': actions, events, processes of consciousness and relations' (Halliday, 1985: 53). To elaborate, once we probe the relationship between the BULIDING conceptual (Source) domain and PERSONIFICATION (as another Source domain), a number of semantic generalisations can be inferred to transmit the scheme of 'building' through personification. Herein, on the basis of the transitivity of the involved processes, personification can be considered an established 'base-model' of the BULIDING metaphorical domain. This base-model provides an implicit cognitive and rhetorical basis for other conceptual models such as THEORIES ARE BUILDINGS of the following sort:

- The laws which construct the basis of this theory are indefensible.

- His argument demolishes the theory from its basis.

- The principles which govern the theory are very constrained.

In spite of the fact that these metaphorical expressions are conventionally analysed as parts of the conceptual metaphor THEORIES ARE BUILDINGS, the processes of constructing, demolishing, and governing are human 'material processes' (according to Structural Functional Linguistics) $)^{(1)}$ which are implicitly refer to human activities which are used concurrently with the BUILDING metaphorical domain. Such understanding of personification in terms of conceptual metaphors is reflected in discourse studies, where "impersonal construction of agency" in action/activity verbs is viewed as one of the central features of discourse (See Biber, 1988; Dorgeloh \& Wanner, 2009; Master, 1991).

\section{Personification in Prophet Muhammad's Tradition}

The analysis of personification in the Prophet Muhammad's Tradition and language shows that the 'semantic tension' (Charteris-Black, 2004) they echo reinforces the several metaphorical elaborations to cover other metaphorical domains. These elaborated images of personification reflect Prophet Muhammad's rhetoric in his lexical selections. These selections are reflected in terms of the different sorts of actions and processes used to convey and emphasize the required message in the Saying and amplify its persuasive power. As highlighted in the following sections, it is found that personification in the Prophet Muhammad's Tradition (henceforth PMT) and language primarily involves the personification of abstract concepts, body parts, and inanimate objects.

\subsection{Personification of Abstract Concepts}

Personification of ideas and abstract notions makes a distinctive mark of human language and thought. Through ages, various people have assigned human qualities to intangible concepts such as courage, wisdom, war, time, life and death. To comprehend their essence of the intangible, people in different cultures have mapped their imagination with their ordinary and essential modest knowledge and experiences. Personified abstract concepts such as birth, hope, knowledge, time, and death are then engaged in explaining and apprehending the matrix of complex connections between people and their experiences. Consequently, the personified experiences have been essentially 'embodied' through myths and folk tales which constituted the set of the alleged assumptions, beliefs, and principles that give acceptable explanations for humans' questions about what they experience but cannot comprehend. Eventually, these personified experiences become established mental representations stored in memory of individual humans and society (Roth and Frisby, 1986: 19).

Early Islamic society was not an exception in this respect. Pre-Islamic Arabs had in their memory the remnants of their ancient myths and folk tales. In addition, their feverish enthusiasm to poetry and rhetoric has amalgamated their metaphors in their both spontaneous and prompted verbal interaction. Thus, early Islamic discourse has benefited from early Arabs' metaphorical competence in ontologically understanding and conceptualising the abstract in terms of the concrete. For instance, CONDUIT metaphors are used to explain the meaning of God worshiping and the performance of most rituals involves. Thus, AlSalat ('daily prayers') is metaphorically understood as a person's COMMUNICATION with (and remembrance) of God. Personification also plays a vital role in recognising the significance of ritual practices and explaining the morals behind their performance and conception. Here, distinctive human traits make abstract concepts understandable and more convincing and sound. In the Prophet Muhammad's Tradition, concepts such as knowledge, poverty, anger, marriage, heaven and hell are systematically conceptualised in terms of human traits. The cycle of time, for instance, is personified using human qualities and behaviours from the conceptual domain of MOVEMENT ALONG A PATH using the image of 'walking'. The idea is illustrated by the Prophet when he elucidated the time of breaking the fast:

1. When the night approaches on this side and the day retreats on that side and the sun sets, he who fasts has reached the time to break it. (Mishkat, n.1954, p. $416)^{(2)}$

Muslims fast the ninth month of the Hijri calendar by abstaining from eating and drinking from dawn to sunset. While the concept of fasting itself is not deemed problematic to the observant Muslim, the duration of fasting and the time it begins and ends may cause certain amount of confusion for the common Muslim observant. Herein, the Prophet asks his Muslim believers to rely on the sound judgement of their senses in observing the duration of fasting. The cycle of day 
and night here is understood by personifying the two notions and depicting their alternation through images of walking expressed through the acts of 'approach' and 'retreat'. The ontological depiction of time passage and the alternation of day and night as a moving person from a distance involve diverse ideas about the manner by which we conceptualise time passage. The passage of time is conventionally conceptualised as a movement from one location to another. In Master Metaphor List, Lakoff (1991) describes time as an object that moves from a point ahead an observer, and he suggests that examples from English such as "When Tuesday comes. ..", "Three o'clock is approaching", "Thursday passed without incident", and "The witching hour is near" involve the employment of the conceptual metaphor TIME IS SOMETHING MOVING TOWARD YOU (Lakoff, 1991: 76).

In the Saying above, both 'night' and 'day' stand for a salient facet of the daily passage of time and are portrayed as two 'objects' involved in a linear movement towards a target. However, 'approaching' and 'retreating' (in Arabic aqbala and adbara respectively) are human, or at least animates, traits and not these of inanimate objects'. These two traits indicate a movement of an animate in relation to a referential point to an observer; and here it is the observant fasting Muslim. In addition, the derivative qualities of Arabic verbs can give us more elaboration about the nature and manner of the actions involved. Both verbs (aqbala and adbara) indicate the side from which the moving person is observed. The verb (aqbala) 'to approach' indicates that 'night' is recognised from the front side ( $q u b l)$ of 'a person's face' while moving towards his side. On the other hand, 'day' is represented as leaving the scene (adbara) 'to retreat' and turning its back (dubr) to the observer. Thus, the implied inference of the two body parts, the face and the back, extends the personified image of the 'night' and 'day' by giving them the human characteristic of moving from one place to another (see Al-Mu'jam al-Waseet 2004, s.v. aqbala and adbara). It is worth adding that the complementary antonymic relationship between the two verbs 'to approach' (aqbala) and 'to retreat' (adbara) implies that both night (allayl) and day (annahaar) are not in comparative scale; in other words, they, like black and white, they make the semantic relation of complementary antonyms as they cannot be in the same time or place together. To do away with any doubt from the part of the observant fasting Muslim about the 'gray' area where both day and night may meet, the Prophet emphasises through his personified image of 'day' and 'night' that they do not eventually co-occur at the same time. Thus, fasting is broken the moment when day leaves and night enters.

Instances of time personification in the PMT are not always opaque and traceable as it is in the Saying above. Certain Sayings involve a sort of implicit mapping of bodily qualities which are best recognised through other elaborations of the same metaphor in the corpus compiled of the Prophet's Sayings. For example, the fasting month of Ramadan is personified again as a person moving in a direction. This image can be implicitly recognised when the Prophet describes the beginning of the fasting month as a process of 'coming' or 'entering'. The Prophet says:

2. When Ramadan begins [enters] the gates of heaven are opened. (Mishkat, n.1956, p. 417)

3. Ramadan, a blessed month, has come to you during which God has made it obligatory for you to fast...."(Mishkat, n.1962, p. 418)

The two Sayings implicitly portray Ramadan as being involved in two sorts of linear movement: 'entering' (dakhala $)^{(3)}$ and 'coming' (ataa). The two human traits suggest the physical and deliberate movement of a human-like figure from a point ahead of an observer to his location. In addition, both verbs 'to enter' (dakhala) and 'to come' (ataa) in Arabic are prominently associated to human reasonable and deliberate actions rather than other creatures or inanimate objects. Remarkably, most uses of the verbs (dakhala) and (ataa) come with human figures when they are used literally (AlMu'jam al-Waseet, 2004: 'dakhala' and 'ataa'), and this entails that Ramadan is portrayed as human figure in the PMT, and it is the conceptual metaphor TIME IS SOMEONE MOVING TOWARD YOU who conspicuously operates within it.

The ontological personified representation of time, 'day', 'night', and 'Ramadan', as moving persons has a significant implication to the point by which Islamic discourse regards time. Such images emphasize the proposition of time's inevitability, a fact that necessitates the inevitability of God's worshipping. Islamic faith states that fasting during the month Ramadan is an obligatory ritual ('a 'rukn' pillar of Islam') that occurs at a precise time of the year. In few explicit cases, such as illness and travelling, the Muslim may be exempted from fasting. Nobody can change the passage of time, or avoid its course, and the personified month of Ramadan is moving in a planned and predestined course towards the observer. Metaphorically, time shall reach the observer's location, and pass it, and the observer can never obstruct or interfere with its course. Accordingly, several rituals and practices of Islam are coincide with specific temporal signs and predestined points. For instance, fasting the month of Ramadan, obligatory charity ('zakaat'), and pilgrimage to Mecca are related to predestined specific time of the year. Therefore, the observant Muslim realises that such rituals and practices are inescapable and unalterable duties when their time is due.

Similar to time, ethical traits, moral values, vices and virtues are also personifies in the PMT. Personification here involves the mapping between intrinsic human actions and abstract spiritual concepts; the Prophet says:

4. Three follow the dead two returning and one remaining with him. His people, his property and his deeds follow him, but his people and property return while his deeds remain. (Mishkat, n.5167, p. 1073) 
The Saying above involves the personification of human deeds as the companion who follows the one from birth to after death. As the human deeds are bestowed with the human capacities of directional movement and free-will, they are given the qualities of the faithful companion who doesn't abandon his companion at death but continues the companionship to the afterlife. This metaphor is an inherent elaboration of the generic conceptual metaphor LIFE IS A JOURNEY to the more specific HUMAN DEEDS ARE A COMPANION IN THE LIFE JOURNEY where the one's actions and deeds are represented as travellers in their shared life journey. The metaphor here reflects the intrinsic relationship between a person and his actions which can lead to his salvation. As the one's own righteous or erroneous actions and deeds will follow him to the Day of Resurrection, these action will be defending their doer before God; defending involves peaking, and speaking is another sort of human capacity.

In addition to the movement example, the Prophet personifies in his Tradition ethical values by attributing to them intrinsic human qualities. Both what is reputable (ma'rouf) and what is disreputable (munkar) are given the human characteristic of speaking:

5. By Him in whose hand Muhammad's soul is, what is reputable and what is disreputable are two creatures which will be set up for mankind on the day of resurrection. What is reputable will give good news to those who followed it and will promise them good, but while what is disreputable will tell them to go away they will be unable to keep from adhering to it. (Mishkat, n.5154, p. 1070)

As the acts of 'giving good news' (bash-shara) and 'promising' (wa'ada), and 'telling' (qaala) are all human capacities, such metaphorical image accentuates the proposal of the life-long relationship between a person and his actions and deeds stated in Saying (4) above. This time, what is reputable (ma'rouf) and what is disreputable (munkar) are portrayed as possessing the human capacity of speaking and defending their doer.

Following the COMPANION image which allegorically depicts the one's actions and deeds as a faithful companion or a false one, we may propose the conceptual personification metaphors GOOD HUMAN DEEDS ARE A FAITHFUL COMPANION and BAD HUMAN DEEDS ARE A FALSE COMPANION. These two conceptual metaphors are common in the Prophet Muhammad's Tradition, and they can be extensively found in several genres of religious and moral discourses. The Prophet also relates 'what is reputable' with two positive actions: 'giving good news' and 'promising them good' which convey pleasant qualities of social relationships. 'Giving good news' (bashshara) and 'promising' ( $\mathrm{wa}^{\prime} \mathrm{ad}$ ) are marked traits in Arabic; they are always used to convey pleasant and positive news. Accordingly, the Prophet accentuates here that faithful companions are ones who bring their companions what makes them feel pleased and contented. Bad and false companions, on the other hand, if they are not harmful, are disinterested in their relationships with their companions. This disappointing conduct is reflected by the use of the synonymous verb 'to tell' (qala) which is used to share either pleasant or distressing news. This proposal is plainly emphasized by a connection between the virtue of 'modesty' (haya'a) and its outcome 'goodness' (khair) in the following Saying:

6. Modesty produces [brings] nothing but good. (Mishkat, n.5071, p. 1053)

Personifying 'modesty' and attributing to it the human ability of 'producing good' contrasts with other negative vices. In another Saying, both 'niggardliness' and 'oppression' are represented as two harmful vices and allegorically personified as the one who is capable to bring destruction and calamity to their bearer:

7. Beware of oppression, for oppression ( $\mathrm{zulm}$ ) will produce excessive darkness (zulumat) on the day of resurrection; and beware of niggardliness, for niggardliness destroyed your predecessors, inducing them to shed one another's blood and to treat things forbidden them as lawful. (Mishkat, n.1865, p. 394)

In this Saying, 'niggardliness' is considered as a counterpart of 'oppression', and the first two actions ('producing' and 'destroying') are not overtly understood in terms of human actions. However, the third action 'inducing' ('hamalahum') explicitly signifies an intrinsic human rational capacity that cannot be performed by non-humans. Such a metaphoric scenario can be regarded as an allegorical representation that has immense command of illustrating complex ideas and concepts in a material and tangible way. As it is widely acknowledged, allegory works on communicating a message by means of symbolic figures, actions or symbolic representation (Kinoslita, 2004). Accordingly, following the FAITHFUL COMPANION and FALSE COMPANION metaphors, good human action, deeds, and qualities stand for good forces of prosperity and welfare for their doers; they can be portrayed as supporters for the believer. Thus, we have the conceptual metaphor GOOD HUMAN DEEDS ARE ONE'S OWN SUPPORTER. On the other hand, bad human deeds and qualities stand for the evil force of self-destruction; they can be portrayed as a destructive force for the sinner. Thus, we have the conceptual metaphor BAD HUMAN DEEDS ARE ONE'S OWN DESTROYER.

In this regards, the personification of such bad desires aims to control them. For instance, people tend to personify their passions using images of the enemy in the battlefield in order to seek aid to fight them back (See Lewis, 1958 (cited in Dodson, 2008)). In addition, personifying 'oppression' and 'niggardliness' aims to put across another moral lesson; the 
connection between personification and other images from the metaphorical domain of LIGHT (darkness) draws attention to the viciousness of darkness. Markedly, metaphors from the domain of LIGHT in addition to the preceding SUPPORTER and DESTROYER metaphors are easily traceable in different genres of religious and moral discourses.

Personifying human actions and deeds in the PMT serves a significant purpose; both sound and vicious actions and deeds conventionally reflect the one's personality and control his behaviours; thus explained metaphorically in terms of a man's actions. These actions are deliberate and purposeful, and they imply the sort of outcome that human deeds can bring to their bearer. The frequent occurrence of the conceptual metaphor HUMAN DEEDS ARE A COMPANION IN THE LIFE JOURNEY and its other metaphorical entailments in the PMT induces the discourse recipient to focus on his own actions and deeds during his journey from birth to death to the hereafter.

\subsection{Personifying Body parts}

One of the distinguished features of the Prophet Muhammad's language is the adept extension of conventional metaphorical images onto creative one. The personification of human body parts in the PMT is noteworthy in its creativity.

Remarkably, most body parts mentioned metaphorically in the Prophet Muhammad's discourse do not conform to conventional EMBODIMENT schemes. In several genres of discourse, body parts are conventionally used to stand for a metonymic representation of an entity by mentioning its parts (Allan, 2008: 10-13; Panther and Thornburg, 2007: 242; Rash, 2006: 78). Antonio Barcelona (2000:16) points out that "the distinction between metaphor and metonymy is scalar, rather than discrete: they seem to be points on a continuum of mapping process".

In Prophet Muhammad's Tradition, it is patent that most of body part metaphors can be classified under the metonymic representation THE PART FOR THE WHOLE where the body parts represent their owners. Personifying body parts here visibly take place when attributing a human quality or behaviour to the body part without overtly referring to its metonymic use. In this regard, body parts are frequently used in the Prophet's Tradition to bestow human qualities, traits, and behaviours which can be categorised in terms of their righteousness. For example, Islam considers fornication ('az-zenaa') a severe breach to the religion and society's ethical codes. People who commit adultery and fornication would be severely punished in their life and on the Day of Resurrection if they did not repent and ask forgiveness for what they committed. The Prophet emphasises that there are several premises which could lead the one to commit adultery and fornication. These premises, the Prophet states, are the result of the partaking of many body parts in committing these acts:

8. God has decreed for man his portion of fornication which he will inevitably commit. The fornication of the eye consists in looking, and of the tongue in speech. The soul wishes and desires, and the private parts accord with that or reject it.”. (Mishkat, n.86, p. 24)

In the Saying above, the Prophet Muhammad personifies body parts by metaphorically bestowing upon them the capacity of performing diverse acts of fornication. He elaborates the personification image by saying that the acts of 'wishing', 'according', 'rejecting', 'desiring', and 'committing fornication' are all human activities performed by body parts 'on behalf' of their owner. Here, the basic meanings of these processes are mostly relatively as mental-activity verbs, and hence bodily-related to the human mind and free-will. Within the context of this Saying, the basic meanings of these processes are more abstract and seem to overlap between a mental-activity verbs and a verb of facilitation and causation (See Biber et al., 1999: 363) in addition to perceptive activity. The Prophet accentuates by such images how the different body parts share with private parts the same guilt of fornication because body parts are not separate parts, but they act according to their owner's wants and desires. The personification of the sorts of fornication which body parts commit suggests that metaphorical fornication is not different in its severity to the sensual one. Thus, premises and actions that could lead to fornication are as sinful as committing sensual fornication.

The metonymic representation THE PART FOR THE WHOLE consistently reflects the manner in which the body parts are used to represent their owner. Meanwhile, it is found that the language of the Prophet Muhammad personifies body parts to map metaphorical relationships which illustrate how body parts contribute in dominating, rather than mirroring, their owners' actions and deeds. This idea is illustrated in the following Saying:

9. When a man gets up in the morning all the limbs humble themselves before the tongue and say, "Fear God for our sake, for we are dependent on you; if you are straight we are straight, but if you are crooked we are crooked." (Mishkat, n.4838, p. 1009)

The Prophet here draws a symbolic scenario of the human-like relationships between the different body parts. Since the tongue makes metonymy for human talk, the prophet emphasizes the severity of what the tongue utters on its owner's fate. The personified image of the tongue goes in parallel with the moral position conveyed from the word 'straight'; herein, we have a mapping between the conceptual metaphor MORALITY IS STRAIGHTNESS, and the personified image of the tongue; 'straightness' is deemed an ideal human value which the tongue must observe.

In addition to the above, body parts are personified by showing their mutual relationships. For example, the following Saying personifies the two hands and showing them competing, whereby each hand performs sound deeds ('sadaqa', giving alms) and conceals what it gives from the other one: 
10. There are seven whom God will cover with His shade on the day when there will be no shade but His: a just imam [ruler]; a young man who grows up worshipping God;....and a man who gives alms concealing it so that his left hand does not know what his right hand bestows. (Mishkat, n.701, p. 142)

As it's perceived in Sayings no. 8 and 9, the actions of 'knowing', 'bestowing', and 'concealing' in the Saying above are intrinsically associated with human capacity. In this Saying, the Prophet incites his follower against hypocrisy and self-pride when giving alms. The finest kind of alms, according to the Prophet, is one given or distributed to the needy in private. The moral proposition of the personified image here is that good deeds, like almsgiving, should not be for one's self-pride and pretence.

Humans are characterised by reasonable thinking and free-will, and their actions and deeds are then deemed either sound or evil. The personification of body parts illustrated above attributes partial responsibility to the body parts and that they, figuratively, have the free-will to control their owner's behaviours. Herein, the personification of body parts in the PMT gives the impression of injustice against the entire body parts because of what one body part did. In this regard, such proposition is refuted by the metaphor THE HUMAN BODY IS A CONTAINER and the metonym THE PART FOR THE WHOLE. One can understand from these mappings that although all body parts function independently, they are subject to their container's commands and control. Thus, the entire body is collectively accountable of the actions of its body parts.

The 'ties of relationships' are consistently represented in the Tradition of the Prophet Muhammad using the metonym ar-rahm ('the womb'). The word 'rahim' in Arabic is derived from the root ' $\mathrm{rhm}$ ' which makes also the root of rahma and rahiim ('mercy' and 'merciful' respectively). Meanwhile, the metonymic representation of the 'ties of relationships' in terms of ar-rahm ('the womb') is frequently represented in the PMT using images of personification. The three Sayings below illustrate such proposition:

11. Three will be under the Throne on the day of resurrection: the Qur'an which will contend with men, having an exotic and an esoteric meaning; the trust; and ties of relationship [ar-rahm, lit.'the womb'] which will say, 'God join those who joined me and sever those who severed me'! (Mishkat, n.2133, p. 452)

12. When God had finished creating all things, ties of relationship [ar-rahm, lit.'the womb'] arose and seized the loins of the Compassionate One. He said, "Stop!" and they said, "This is the place for him who seeks refuge in Thee from being cut off." He replied, "Are you not satisfied that I should keep connection with him who keeps you united and sever connection with him who severs you? "They [ar-rahm, lit.'the womb'] said, "Certainly, O Lord," and He replied, "Well, that is how things are. (Mishkat, n.4919, p. 1025)

13. Ties of relationship [ar-rahm, lit.'the womb'] are tied to the Throne and say, "With him who keeps me united God will keep connection, but with him who severs me God will sever connection.” (Mishkat, n.4921, p. 1025)

The Prophet uses the metonymy of the womb to stand for blood ties of relationship. This involves the affectionate relationship between the child and his parents, brothers, siblings, and relatives. In addition to their emotional appeal, such social relationships construct the bases of all social structures in the Muslim society. What is more, the rendition of the Arabic 'rahm' into English 'ties' implies that the relationships between relatives and members of the same family are not casual and temporary; instead, it is a binding relationship of blood that cannot be, and should not be, resolved. Personification here is most useful in the division under amplification and in appeal to pity (Demetrius, 1927 (cited in Paxson, 1994: 13)).

Our body parts play a crucial role when creating an ontological meaning or building an ideological discourse message. Human capacity to deduce meaning and understand the content of a discourse considerably relies on body part metaphors. The relationship between the personified body parts and their associated actions and deeds can be seen as involving a metaphorical relationship in which the human body is seen as a container for its parts. Body parts have in common the human capacity to act; entailing that both the source and target domain of the metaphorical mapping involve human actions. It follows that the mapping process between abstract concepts to concrete images of people who are performing certain actions extends the understanding capacities of the discourse recipient. In all, the source domains associated with the most frequent instances of personification in the PMT seem to be related to the (human) body, specifically, in its capacity to create, handle, move and perceive. Accordingly, the common source domain of the perceived conceptual mappings of personification is the intrinsic human capacities.

\subsection{Personifying Inanimate Objects}

Aristotle ones describes personification as 'Homer's common practice of giving metaphorical life to lifeless things, (Aristotle, 1954 (cited in Paxson, 1994: 12)). In this lies the real meaning of personification when life is bestowed upon lifeless objects. Inanimate objects are also personified the PMT by bestowing upon them different intrinsic human capacities and behaviour. The variety of the personified objects can be illustrated through the variety of metaphorical 
and semantic domains which are involved in personification. In the PMT we notice that several non-living entities, places, commodities, and natural elements are bestowed with the human capacities of performing actions and having the free will. The following Sayings illustrate:

14. The last hour will not come before Medina drives away its wicked people as the bellows drives away the impurity of iron. (Mishkat, n.2740, p. 588)

15. The wind comes from God's mercy bringing blessing and punishment, so do not revile it, but ask God for some of its good and seek refuge in Him from its evil. (Mishkat, n. 1516, p. 317)

16. Usama b. Zaid said: God's messenger sent us to some people of Juhaina, and I attacked one of them and was about to spear him when he said, "There is no god but God." I then speared him and killed him, after which I went and told the Prophet. He said, "Did you kill him when he had testified that there is no god but God?" .... [and he] reported as saying several times, "How will you deal with 'There is no god but God' when it comes on the day of resurrection ?”. (Mishkat, n. 3450, p. 734)

17. Jabir said that the area round the mosque was vacant and that the B. Salima wanted to remove near the mosque, but when the Prophet heard of that he said to them, "I have heard that you want to remove near the mosque." They replied, "Yes, messenger of God, that was our desire." He said, "B. Salima, if you keep to your present houses, your footprints will be recorded [by your houses] ${ }^{(4)}$; if you keep to your present houses, your footprints will be recorded." (Mishkat, n. 700, p. 142)

The first Saying (no. 14) illustrates a metaphorical relationship that involves the general metonymic principle THE WHOLE FOR THE PART. The Prophet's home town (Medina) is metonymically bestowed with human qualities and to stand for its inhabitants following the metonym THE PLACE FOR ITS INHABITANTS. Thus, the act of 'driving away' of the wicked will be performed and achieved by the inhabitants of Medina. Remarkably, this image involves a matrix of mappings between different metaphorical domains where the personification image, the metonym, the action of 'driving away' (tanfi), and the image of the 'bellows' all reflect the metaphor A MUSLIM COMMUNITY IS A CONTAINER. This conceptual metaphor is derived from the political metaphor A STATE IS A CONTAINER. Medina, where the Prophet and his followers live, is portrayed as the smith who drives away the impurity of iron, or the 'wicked people'. This matrix of metaphorical images and mappings entails the Prophet certainty of the action of 'driving away' because it is attributed to the town rather than to its inhabitants. Accordingly, the action is depicted everlasting rather than temporal, and it is then not associated with specific time and specific people.

In Saying no. 15 above, the wind is bestowed the human capacity of bringing either the good or the bad to mankind. The wind is a natural phenomenon, and the Saying induces Muslim to accept what the wind brings as a demonstration of God's will. The wind is personified here to give it the image of the servant who subdues to the orders of his master. Therefore, both people and the wind are depicted as the SERVANTS of God; a metaphorical mapping that is common in Islamic religious discourse.

Meanwhile, Saying no. 16 involves the personification of the expression of al-Shahadah ('testimony') 'there is no god but God'. This expression is considered the first pillar of Islam, and it signifies the faith or belief in the Oneness of God and the conclusiveness of the 'prophethood' of Muhammad. This expression is considered as the Muslim's own declaration of his belief in God and that the chief purpose of life is to serve and obey God. al-Shahadah is personified as a defendant who will come on the Day of Resurrection to defend the one who uttered it in full faith in his life because it is a testimony of the person's faith and submission to God's orders. In this regard, the Prophet accentuates the severity of what his companion Zaid did by hastily killing a man who said al-Shahadah. The Prophet blames Zaid, and his followers, who may wrongly judge the faith of others. Uttering al-Shahadah, according to the Islamic faith, signifies that the person now affiliates himself to Islam; thus, his blood must not be shed. The personification of al-Shahadah following the metaphor GOOD HUMAN DEEDS ARE A FAITHFUL COMPANION re-emphasizes the relationship between what we say in our life because what we say makes either sound or bad deeds. These deeds will come on the Day of Resurrection to defend their doers and prove either their belief or disbelief in God.

In Saying no. 17, the Prophet Muhammad creatively personifies the houses of those who observe prayer at mosque. Living at a distance from the mosque, Bani Salima finds it difficult to observe all the five prayers at mosque. The Prophet promises his followers here that their reward will be boosted because their houses record their footprints when they go to the mosque. The personification of the houses explicitly complements and emphasises the previous point about how sound actions and deeds are the Muslim's GOOD COMPANION.

The Personification of non-living entities in the PMT emphasizes that God's will is inevitable and must be achieved regardless of time or inadvertent circumstances. In addition, the personification of places (Medina and houses) and the testimony expression 'no god but God' puts emphasis on the prominence of God's justice in his judgement. God recruits different SERVANTS to record peoples' actions and deeds; and among them, in addition to the angels, he has 
employed those inanimate objects who act justly on behalf of God. These SERVANTS are depicted as objective and faithful to their duties to God when they record what people do.

\section{De-personification}

De-personification is the opposite of personification; it is the removal of intrinsic human qualities of the de-personified person and substituting them with qualities conventionally attributed to non-humans or an inanimate objects. Generally, metaphors of de-personification can be analysed in terms of other metaphorical domains. However, it is found that most instances of de-personification in the PMT involve unconventional sorts of mapping between the conceptual domains to enhance their persuasive power. De-personification in the PMT can be categorized as involving animals, plants, and inanimate objects.

\subsection{De-personification Involving Animals}

The purpose of de-personification involving animals varies according to the context. For example, it can be used to dignify a name by bestowing upon him an animal's well-liked sound behaviour or trait. For instance, courage is a deemed an admired quality of the lion and bestowing it to a man gives him a heroic eminence (e.g. Achilles jumped as a lion). Cowardliness, on the other hand, is a dishonourable attribute; it is used to denigrate somebody by using a conventionally disrespected animal that is known for this conduct (e.g. you should not hide your head in the sand like an ostrich; and he ran from the place like a chicken).

De-personification involving animals occur occasionally in the PMT especially when categorising people according to their belief and faith. The believers, on one hand, are de-personified favourably by attributing to them admired and sound animal traits. On the other hand, sinners and disbelievers are given detestable traits. For example, the Prophet says:

18. I [the Prophet] may be likened to a man who kindled a fire, and when it lit up the neighbourhood insects and these creeping things which fall into a fire began to fall into it. He began to prevent them, but they got the better of him and rushed into it. Now I am seizing your girdles to pull you from hell, but you are rushing into it. (Mishkat, n. 149, p. 41)

The Prophet metaphorically characterises sinners by the conceptual metaphor SINNERS ARE INSECTS WHO FALL INTO FIRE which makes an extension of the conceptual GREAT CHAIN OF BEING metaphor. This metaphorical mapping is used to classify beings or entities on the basis of a hierarchal vertical scale; or a 'gradation principle' (see Rash, 2006: 115). Naturally, divine beings are situated at the top of this hierarchical scale, and they are followed by human beings. The lowest degree is allocated for lower forms of beings such as insects and bacteria (Rash, 2006: 115). Accordingly, insects and 'creeping things' are used here to demean a name or a group of people because they are characteristically considered creatures of inferior hierarchy in the animal kingdom. The Saying above extends this metaphorical hierarchical scale in which the Prophets, and the believers, are positioned in an elevated hierarchal status and the sinners in an inferior one. According to the Prophet's GREAT CHAIN OF BEING metaphor, human deeds are the norm by which his status is being judged according a hierarchical scale and good actions and deeds are categorized in terms of GOOD IS UP and the bad ones are categorized by BAD IS DOWN metaphor.

The de-personification image above shows how people's destiny is plotted in accordance with their status and deeds in life. Sinners and disbelievers who refuse the God messenger's guidance will fall, by their own will and deeds, into hell in the same manner as the insects and creeping things do. The metaphor SINNERS ARE INSECTS illustrates here the triviality, ignorance, and lack of reasonable judgement in the part of sinners, and this reflects their insignificance. In addition, the image of the sinners' persistence to commit sinful deeds contrasts with what the Prophet tries hardly to do in saving them from falling into fire. The phrase 'got the better of him' accentuates the Prophet's devotion to his mission in protecting mankind from their ignorance and obstinacy which may lead to their eternal punishment and fall into Hell. This contrast between what the prophets do and the reaction of ordinary people to the Prophets' endeavour puts emphasis on the importance of prophets to mankind. For instance, the LIHGT metaphor here refers to the message of Islam that replaces darkness pre-Islamic period.

On the other hand, the believers are constantly bestowed with favoured animal traits. To illustrate, camels and horses are admired animals in Arabic culture; thus, they occupy a higher position in their GREAT CHAIN OF BEING hierarchy. The Prophet refers to the qualities and fine traits of these animals to underline several fine qualities that his followers acquired by joining Islam. The Prophet says:

19. The believers are gentle and kindly like a tractable camel which when guided lets itself be guided and when made to sit even on stones does so. (Mishkat, $\mathrm{n}$. 5086, p. 1055)

20. The believer and faith are like a horse with the stake to which it is tethered, which moves round and then returns to its stake, for the believer is negligent and then returns to faith. Feed the pious with your food and confer your kindness on the believers. (Mishkat, n. 4250, p. 900) 
The Prophet emphasizes here the fine qualities of the believers by comparing them to the fine qualities of camels and horses. He praises by such comparison the believer's blind and willing obedience of his Lord in the same manner the tractable camel subdues to his owner. This obedience originates from the believer's absolute faith on God not because of pain as one may wrongly infer from the metaphorical image. This proposition accentuates the fact that depersonification aims chiefly to foreground the idea of obedience rather than the status of the believer. The same is true about Saying no. 20 where the de-personification of the believer as a horse points at how true believers are bound to their faith. Accordingly, once the believer commits a sin and been led astray, his true faith restrains him from continuing in his sinful deeds, and he will be returned towards the true path.

Meanwhile, believers are sometimes de-personified in the PMT by comparing their wrong deeds to unfavourable animals' behaviour. In this case, the wrong deeds are overtly emphasised to put emphasis on the severity of the sin. For example:

21. If anyone helps his people in an unrighteous cause, he is like a camel which falls into a well and is pulled out by its tail. (Mishkat, n. 4909, p. 1022).

The Prophet points her to the severity of tribalism and intolerance which was common at his age. The Prophet condemns by this image the one who pride himself by his ethnic or tribal affiliations. Those who praise the social status of their tribes or defend them in their wrong doings are compared to the ones who try to pull out a camel that is entrapped in a well by its tail. Here, the behaviour of the boasting man in the metaphoric scenario is what is mostly emphasized. Meanwhile, the de-personification of the tribe as a fallen camel aims to demonstrate the gravity of tribalism and intolerance and its actual status; but the animal itself is not reviled.

It can be perceived that images of de-personification involving animals in the PMT generally portray sinners and disbelievers using ostracized and pejorative qualities and traits of animals. The believers, on the other hand, are depersonified by being bestowed with fine and admired qualities and traits of well-liked animals. De-personification here is drawn from following several metaphoric images and scenarios which are based on the GREAT CHAIN OF BEING and GOOD IS UP and BAD IS DOWN metaphors. These conceptual metaphors have their roots in different types of discourse. In religious language and discourse, these metaphors convey a large variety of moral messages especially through the categorization of people according to their fine or bad actions and deeds. Such categorization is primarily aligned on the basis of the degree of these people's faith and belief in God.

\subsection{De-Personification Involving Plants}

Plants and trees are indispensable elements of life; they provide food and shelter for many species including humans, and they stir up our delight by their smell, taste, and sight. Consequently, it is not out of the ordinary that plants are one of the most favoured domains used metaphorically in language.

The Prophet Muhammad frequently de-personifies both the believers and the disbelievers using images from the PLANTS conceptual domain with the believers are more frequently depicted. This can be attributed to the proposition that the fine qualities of plants and trees are more salient than the bad ones; if there is any. For instance, the believers are constantly bestowed with the most admirable qualities of plants such as good flavour, odour, and resilience. The Prophet says:

22. The believer is like a plant which is continually swayed by the wind, for the believer is continually afflicted by trial; but the hypocrite is like a cedar tree which does not shake till it is cut down. (Mishkat, n. 1542, p. 323)

23. A believer who recites the Qur'an is like a citron whose fragrance is sweet and whose taste is sweet, a believer who does not recite the Qur'an is like a date which has no fragrance but has a sweet taste, a hypocrite who does not recite the Qur'an is like the colocynth which has no fragrance and has a bitter taste, and the hypocrite who recites the Qur'an is like basil whose fragrance is sweet but whose taste is bitter. (Mishkat, n. 2114, p. 447)

The two Sayings metaphorically distinguish different types of people, believers and hypocrites, according to their faith in God by foregrounding behaviours and traits and compare them to different qualities of trees and plants; such as their firmness, taste, and fragrance. Saying no.22 puts emphasis on to the sturdy character of the cedar tree in a negative rather than a positive way when attributed to the hypocrites. The wooden stem of the cedar tree wood is recognised by its capability to stand against hard natural phenomena like winds and rainy weather. However, this fine quality of the cider tree is negatively fore-grounded in the de-personification image of hypocrites because string wind can break, or even uproot, it. Hypocrites, or infidels, cannot stand hardships and calamities of time despite of their apparent strength because of their lack of faith. Meanwhile, Saying no. 23 too is filled of positive de-personification images involving plants which can be perceived through the senses of smelling and tasting. Here, the Prophet illustrates the intrinsic qualities of people in terms of their faith and recitation of the Holy Quran. Different types of fruit are used here to classify people according to their faith to reflect how the Prophet perceives his people, the Arabs. The Prophet promotes in his set of images what Arabs already knew and recognised by their senses and experiences and provokes them to liken their experiences with his own proposition about the different types of people. 
Metaphors from the domain of plants and fruits in the Prophetic Tradition extend the intended meanings of the depersonification metaphor to elaborate several unconventional meanings at the expense of the most salient ones. The embodied experiences of smelling and tasting which may arouse strong feelings make sensual experiences most suitable for being used metaphorically and in different kinds of discourse (Rash, 2006: 132). For example, Saying no. 23 above employs images from the conceptual metaphor BELIEVERS WHO RECITE QURAN ARE FRUITS which can be regarded as an elaboration of the conceptual metaphor PEPOLE ARE PLANTS. Depicting a true believer who recites the Quran as a citron attracts the listener's attention to the different external and internal qualities of this fruit such as its attractive odour, colour, and soft skin rather than any other lamentable qualities. Herein, the significance of this image for the discourse is highlighted through our knowledge that this fruit was mostly known and preferred by Arabs for its sweet taste and for its use in medication. Then, the one who recites the Holy Quran is compared to the physician who heals diseases.

\subsection{De-Personification Involving Inanimate Objects}

De-personification in the PMT involves bestowing features and actions of different inanimate objects on people. Most metaphors here are mapped through processes attributed to inanimate objects such as BUILDING. For instance, The Prophet refers to the BUILDING conceptual domain to describe the fine qualities of different categories of people such as their solidarity, firmness, and strength. He says:

24. The way in which I may be compared with the prophets is by a castle which was beautifully constructed, but in which the place of one brick was left incomplete. Sightseers went round admiring the beauty of its construction with the exception of the place for that brick. Now I have filled up the place of that brick, in me the building is completed and in me the messengers are complete. (Mishkat, n. 5745, p. 1231)

25. Believers are to one another like a building whose parts support one another." He then interlaced his fingers. (Mishkat, n. 4955, p. 1032).

In Saying no. 24, the BUILDING metaphorical domain is used to illustrate the Prophet's status as the last prophet. Meanwhile, the process of building can be seen as a representation for the continuity of the divine message and its timelessness. Herein, the Prophet implies that his message is not 'new', but it is a continuation of what other prophets already accomplished. In Saying no. 25, the Prophet accentuates the idea of solidarity between members of Islamic society by depicting Islamic society as the one human body whose parts are affected by the infection that may hit any other organ. This image follows the metaphor THE MUSLIM COMMUNITY IS A BODY which is an elaboration of the metaphor A STATE IS A CONTAINER and A BODY IS A CONTAINER. These two conceptual metaphors illustrate the inherent mutual relationships between the different components of society in which the people's (the contained) individual and self-centred interests are marginalised in favour of the group's (the container) interests.

\section{Conclusion}

In terms of function, the Prophet Muhammad's Tradition constitutes a very important body of Islamic religious discourse. Analysing instances of personification and de-personification as parts of metaphorical language in such discourse reveals their prevalent overlap with different conceptual metaphorical domains. In addition, the Prophet Muhammad's Tradition constitutes a heterogeneous body of themes and topics which has a variety of messages and purposes. This fact makes the Prophet Muhammad's Tradition and religious discourse, unlike political discourse, difficult to be dissected in order to reveal a particular evocative ideological implication. Conversely, the metaphors involving de-personified images can be interpreted as conveying ontological meaning and carrying a more prevalent ideological implication. Given the ubiquity of the first assumption, the second assumption is illustrated whereby people are classified into a hierarchical scale according to the degree of their faith and the nature of their deeds and behaviours. Taking the two assumptions above, one can hinge on Webster's argument in such comparable respect that authors would use personification as a means of explaining the abstract and of persuading the reader of the importance of the image personified (Webster, 1954 (cited in Dodson, 2008)), and the same, I argue, can be said about de-personification. The frequent use of personification in the PMT may thus be one area that distinguishes religious language and discourse in terms of the manner metaphor-related verb use can be perceived. Such proposition can be consolidated by posing that active verbs with inanimate (personified) subjects in religious language and discourse exert the predominant functions of indicating both causation and explaining.

In terms of form, it is noticed that the personified images employed by the Prophet Muhammad that they follow consistent patterning regardless of their conceptual domains. In the first respect, the Prophet tends to personify abstract concepts, body parts, and human deeds by overtly showing both the source (the vehicle) and the target (the topic) domains of the personification image. Then, he elaborates the message by explaining, in a few words, the common respect of the analogy between the source and target domains (the ground). This strategy makes the Prophet's message and proposition in the Saying lucid and concise and simple to recognise and comprehend. Despite that, the personified, and de-personified, images engross a variety interpretations and implications.

Commenting on the necessity of personification in PMT, personifications, as a type of metaphorical language, can be seen as an exceptionally concise, readily imaged, and easily remembered means of communicating moral and didactic messages and shaping thought and faith. The peculiar advantage of personification in religious language and discourse 
relies on its vividness and 'memorability'. Moreover, personifications are interesting to the listener in a way in which direct expressions are not. The personified images in PMT resemble masquerades in which the goal is to see through the disguises to the human beings underneath. In the religious context, such disguise (or mental-masking) can entail some degree of excitement and emotional involvement. This emotional involvement may in turn be related to the assumptions that the believers dream about a heavenly world where everything is morally perfect and different from what they experience in their earthly life. In addition, personifications also provide a more effective means of shaping thought that can defy counterexamples which come readily to mind. Images of personifications have a fable-like quality that inspires suspension of disbelief and that makes it difficult to question the underlying moral and religious messages, and sometimes ideologies. One may suggest that the personified images of abstract concepts such as human deeds, virtues and vices may be challenging in their inferences; especially, once non-human entities are bestowed the gift of 'life' rather than any other intrinsic human capacity. For example, Sayings 5, 11, 12, 13, and 16 involve bringing life to inanimate non-human entities at the world of the 'unknown' or on the Day of Resurrection. Such images could be subject to a variety of religious inferences and interpretations regarding the literal or metaphoric 'truth' of these scenarios; a question that should be addressed by other disciplines in addition to linguistics and discourse analysis.

\section{References}

Mishkat-ul-Masabih. (1960-65). A Collection of Prophetic Tradition. By Al-Khatib, Muhammad ibn `Abd Allah, English translation with explanatory notes by James Robson. Lahore: Sh. Muhammad Ashraf.

Al-Mu'jam, al-Waseet. (2004). Arabic Monolingual Dictionary compiled by The Arabic Language Complex. Cairo: Maktabat alShorouq alDawliyah

Allan, K. (2008). Metaphor and Metonymy: A Diachronic Approach. Publications of the philological Society, 42. Oxford: Wiley Blackwell.

Barcelona, A. (2000). Introduction: The Cognitive Theory of Metaphor and Metonymy. In A. Barcelona (Ed.), Metaphor and Metonymy at Crossroads: A Cognitive Perspective. (pp. 1-28). Berlin: Mouton de Gruyter.

Bender, A. P. (1894). Beliefs, Rites, and Customs of the Jews, Connected with Death, Burial, and Mourning. The Jewish Quarterly Review, 6 (2), pp. 317-347.

doi: $10.2307 / 1450143$

Biber, D. (1988). Variation across Speech and Writing. Cambridge: Cambridge University Press.

Biber, D., Johansson, S., Leech, G., Conrad, S., and Finegan, E. (1999). The Longman Grammar of Spoken and Written English. London: Longman

Charteris-Black, J. (2004). Corpus Approaches to Critical Metaphor Analysis. London: Palgrave Macmillan.

Cuddon, J.A. (1998). The Penguin Dictionary of Literary Terms and Literary Theories. (4 ${ }^{\text {th }}$ ed.). Oxford: Blackwell Publishers.

Dodson, J. (2008). The Power of Personification: Rhetorical Purpose in the Book of Wisdom and the Letter to the Romans. NY: Walter de Gruyter.

Dorst, A. G. (2011). Personification in Discourse: Linguistic Forms, Conceptual Structures and Communicative Functions. Language and Literature, 20(2), pp. 113-135.

doi: 10.1177/0963947010395522

Dorgeloh, H., \& Wanner, A. (2009). Formulaic Argumentation in Scientific Discourse. In R. Corrigan, E. A. Moravcsik, H. Ouali and K. M. Wheatley (Eds.), Formualic language (Vol. 2: Acquisition, loss, psychological reality and functional explanations, pp. 523-544). Amsterdam: John Benjamins.

doi: $10.1075 /$ tsl.83.16dor

Eubanks, P. (2000). A War of Words in the Discourse of Trade: The Rhetorical Constitution of Metaphor. Carbondale: Southern Illinois University Press.

Gibbs, R. (1996). Why Many Concepts are Metaphorical. Cognition, 61, pp. 309-19.

Gibbs, R. (1994). The poetics of mind: Figurative Thought, Language, and Understanding. UK: Cambridge University Press.

Grady, J. (1997). A Typology of Motivation for Conceptual Metaphor: Correlation vs. Resemblance. In R. W. Gibbs and G. J. Steen (Eds.), Metaphor in Cognitive Linguistics. Selected papers from the fifth international cognitive linguistics conference. (pp. 79-100). Amsterdam: Benjamin's.

doi: 10.1075/cilt.175.06gra

Halliday, M. A. K. (1985). An Introduction to Functional Grammar. London: Edward Arnold.

Hamilton, C. A. (2002). Mapping the Mind and the Body: On W.H. Auden's Personifications. Style, 36 (3), pp. 408427.

Kinoslita, R., (2004). Reception Theory. University of California Santa Barbara: Department of Art. [Online] Available: http://www.yumikinoshita.com/receptiontheory.pdf (July 7, 2015).

Klaus-uwe P. and Linda L. T. (2007). Metonymy. In D. Geeraerts, and H. Cuyckens (Eds.), The Oxford Handbook of Cognitive Linguistics. (pp. 236-263). Oxford: Oxford University Press.

Kövecses, Z. (1995). American Friendship and the Scope of Metaphor. Cognitive Linguistics, 6, pp. 315-346.

doi: $10.1515 / \operatorname{cog} 1.1995 .6 .4 .315$

Lakoff, G. and Johnson, M. (1980). Metaphors we Live by. Chicago: The University of Chicago Press.

Lakoff, G. (1987). Women, Fire, and Dangerous Things. Chicago: University of Chicago. 
Lakoff, G. and Turner, M. (1989). More Than Cool Reason: The Power of Poetic Metaphor. Chicago: University of Chicago Press.

Leech, G. N. (1969). A Linguistic Guide to English Poetry. London, Longman.

Master, P. (1991). Active Verbs with Inanimate Subjects in Scientific Prose. English for Specific Purposes, 10 (1), pp. 15-33.

doi: 10.1016/0889-4906(91)90013-M

Paxson, J. (1994). The Poetic of Personification. Cambridge: Cambridge University Press.

Peters, P. (2004). The Cambridge Guide to English Usage. Cambridge: Cambridge University Press.

Rash, F. (2006). The Language of Violence. New York: Peter Lang.

Roth, I. and Frisby, J. (1986). Perception and Representation: A Cognitive Approach. New York: Open University Press.

\section{Notes}

(1) Systematic Functional Linguistics is a linguistic theory that examines the functions that language performs in terms of the purposes it serves in a society (See Michael Halliday's Introduction to Functional Grammar (Halliday, 1994)).

(2) All the translations of the sayings are obtained from James Robson's translation of Mishkat Al-Masabih; the first number after the Saying indicates the saying's number according to the Arabic version; the second number indicates the page number in Robson's translation.

(3) The literal translation of the Arabic verb (dakhala) is 'entered', but the translation has 'begin' to signify that the fasting month of Ramadan is time notion that has a beginning and an end.

(4) The literal translation of the phrase is "your houses record your footprints", and it occurs in the active mode, not passive mode. 